\title{
Saffron (Crocus sativus L.) Crop Insurance to Mitigate ill Effects of Climate change - a Priority of Jammu and Kashmir State
}

\author{
F.A. Nehvi* and Salwee Yasmin \\ Sher-e-Kashmir, University of Agricultural Sciences and Technology of Kashmir, India \\ *Corresponding author
}

\section{A B S T R A C T}

\begin{tabular}{|l|}
\hline K e y w o r d s \\
Insurance, Weather, \\
Yield loss, Saffron, \\
Jammu and \\
Kashmir \\
\hline Article Info \\
\hline $\begin{array}{l}\text { Accepted: } \\
\text { 22 December } 2018 \\
\text { Available Online: } \\
\text { 10 January } 2019\end{array}$
\end{tabular}

\section{Introduction}

After implementation of National Saffron Mission in 2010 by Agriculture Production Department $\mathrm{J}$ and $\mathrm{K}$ Saffron farming system a legendary crop of Jammu and Kashmir state was on rise up till 2013, as overall Saffron production of state increased from 9.46 M.T to 16.5 M.T with an increase in average productivity from 2.5 to $4.4 \mathrm{~kg} / \mathrm{ha}$ (Nehvi and Salwe, 2017). However, excess precipitation observed in 2014 by 53\% (280 mm as against requirement of $183 \mathrm{~mm}$ ) during sprouting stage (August-October) lead to decline in saffron production of $\mathrm{J}$ and $\mathrm{K}$ state by $70 \%$ (4.5 M.T as against 15 M.T recorded during 2013). Similarly, precipitation deficit during sprouting stage recorded by $56.9 \%$ in 2016 and $100 \%$ in 2017 lead to decline in saffron production by $91 \%$ during 2017 (from 16.5 M.T recorded in 2015 to 1.5 M.T recorded in 2017). Excess summer precipitation associated with high humidity has become concern of saffron growers as during 2015 saffron growers lost about $30 \%$ of corms due to corm rot caused by fungal infestation as saffron area recorded $400 \%$ more precipitation from May to July $(550 \mathrm{~mm}$ as against normal precipitation of $110 \mathrm{~mm}$ ) Figure 1 and 2 (Salwe et al., 2016). All these factors have resulted in annual exchequer loss to the tune of Rs 225 cores during 2017 affecting about 
17000 saffron families involved with saffron farming system directly or indirectly. Alarming situation made farmers despondent about future of saffron and thus introduction of crop insurance policy for saffron is the only way to make saffron growers confident about future of saffron under changed climatic conditions of Kashmir.

\section{Materials and Methods}

\section{Weather Based National Crop Insurance Programme (NCIP) For Saffron.}

\section{Premium}

To gain the confidence of farmers dealing with any legendary cropping system it is legitimate duty of Government of that particular state to notify a crop insurance scheme. Accordingly Agriculture Production Department notified implementation of National Crop Insurance Programme (NCIP)-/Rashtriya Fasal Bima Karyakram -Weather Based Crop Insurance Scheme(WBCIS)-component in J and K State during the year 2014-15 as per the guidelines and operational modalities fixed by Department of Agriculture and Cooperation, MOA,GOI vide letter No. 13015/02/2012Credit-II, dated 04.02.2014. Trigger points for different phonological stages of saffron were identifies as base line values for water and temperature requirements (Salwee et al, 2018).The strike values were calculated on the basis of deficit and excess rainfall and decrease and increase in day temperature. Pay out rates were calculated on the basis of cost of cultivation and the extent of damage during particular phonological stage. As per the operational guidelines of NCIP, the total premium will be shared as per details in Table 1 .

\section{Adoption level}

The scheme will be applied to the Jammu and Kashmir and saffron crop will be taken up for insurance on pilot basis. The period of coverage for saffron crop will be from $1^{\text {st }}$ August, to $31^{\text {st }}$ May. All the farmers including small and marginal, women, Schedule Caste, Sharecroppers, tenant farmers growing the Notified Crops in the Notified Area are eligible and will be covered under the scheme if they availed Seasonal Agriculture Operations (SAO) loans from financial institutions (i.e. Loanee farmers) or nonloanee farmers who opt for the Scheme. About, $1000 \mathrm{Ha}$ of Saffron crop area in 18 agricultural circles viz., Zantrag, Khrew, Wuyan-A. Wuyan-B, Sharshali-A, SharshaliB, Jawbehara, Lethpora-A, Lethpora-B, Lethpora-C, Samboora, Parigam, Konibal-A, Konibal-B, Chandhara, Namblabal, Drangbal and Kadlabal will be allotted to different National insurance implementing agencies. They will be made responsible for wide publicity regarding the scheme in their respective areas of jurisdiction to create awareness among the farmers and lay down of the entire requisite infrastructure of Automatic Weather Stations (AWS). The already installed AWS, if any, by IMD/SAUs in the notified areas will be used as RWS for implementation of the scheme

\section{Pradhan Mantri Fasal Bima Yojna (PMFBY)}

In 2017, State Agriculture Production Department notified Pradhan Mantri Fasal Bima Yojna (PMFBY., 2016) for saffron Insurance to support sustainable production of saffron by way of - a) providing financial support to farmers suffering crop loss/damage arising out of unforeseen events b) stabilizing the income of farmers to ensure their continuance in saffron farming c) encouraging farmers to adopt innovative and modern agricultural practices d) ensuring flow of credit to the agriculture sector; which will contribute to saffron farming security. For assessment of yield losses crop cut experiments is mandatory to be carried by 
Insurance companies in collaboration with a team of technical experts to be designated by the Nodal officer at district level. As CCEs is not available for saffron therefore SKUASTKashmir developed guidelines for Crop Cut Experiment (CCEs) for saffron.

For designing CCEs in saffron following methodology was taken into consideration viz;

- Basic Principles.

- Steps in different activities in Crop Cut Evaluation

- Procedure for Selection of saffron growers plot (experimental site) for taking crop cut

- Experimental materials required

- Locating an Experimental Plot for Crop Cutting Experiments (Square plot of Size $5 \times 5 \mathrm{~m})$

- Flower Picking and other operations (Nehvi et al., 2018)

\section{Results and Discussion}

\section{Weather Based National Crop Insurance Programme (NCIP) For Saffron}

\section{Trigger weather}

In saffron availability of moisture during sprouting stage is considered the trigger weather to induce saffron flowering on account of development of adventitious roots that helps in better sprout activation. Trigger Weather is pre-defined and notified w.r.t a particular weather parameter, and is being fixed keeping in mind the broad moisture/water or other weather parameter requirement of a particular crop. During this period saffron crop should receive $2290 \mathrm{~m}^{3}$ of water per hectare to ensure quick and timely sprouting leading to high productivity (Nehvi et al., 2017).

Saffron flowering is another most critical phonological stage and is mostly influenced by high aerial temperatures $\left(>20^{\circ} \mathrm{C}\right)$ and low night temperatures $\left(<6^{\circ} \mathrm{C}\right)$. Although flower ontogenesis process is completed after the plant receives desired moisture but deviation of maximum and minimum temperatures from desired levels during flowering period (October) results in delayed flowering $\left(\mathrm{I}^{\text {st }}\right.$ week of November) leading to flower abortion within the cataphyll shoots. In Kashmir, saffron would usually flower during $2^{\text {nd }}$ week of October recording day and night temperatures within permissible limits i.e $17^{0} \mathrm{C}-19{ }^{0} \mathrm{C}$ during day and $8{ }^{0} \mathrm{C}$ to $11{ }^{0} \mathrm{C}$ during night.

However climate change observed in the last couple of years recorded conducive temperatures for saffron flowering only during $\mathrm{I}^{\text {st }}$ fortnight of November thereby reducing the flowering period to just 10 days. Low night temperatures recorded during flowering period of November lead to production losses due to poor flower development.

Table.1 Premium details of saffron crop insurance under weather based NCIP

\begin{tabular}{|l|c|}
\hline Crop Covered & Premium/ha(Rs) \\
\hline Sum Insured & 825000 \\
\hline Total Premium & 99000 \\
\hline Farmer's Share of Premium & 49500 \\
\hline Central Share of Premium & 24750 \\
\hline State Share of Premium & 24750 \\
\hline
\end{tabular}


Table.2 Revised weather based crop insurance scheme (2018-19)-Term Sheet

\begin{tabular}{|c|c|c|c|c|c|c|}
\hline \multicolumn{3}{|c|}{ State } & District & Crop & $\begin{array}{l}\text { Reference } \\
\text { weather Station }\end{array}$ & Unit \\
\hline \multicolumn{3}{|c|}{ Jammu and Kashmir } & $\begin{array}{l}\text { Pulwama, } \\
\text { Budgam, } \\
\text { Srinagar, } \\
\text { Kishtwar }\end{array}$ & Saffron & Pampore & Hectare \\
\hline \multicolumn{7}{|c|}{ Term Sheet } \\
\hline S No & \multicolumn{2}{|c|}{ Weather Parameter } & Phase I & Phase II & Phase III & \\
\hline \multirow[t]{9}{*}{1} & \multirow[t]{9}{*}{$\begin{array}{l}\text { Deficit } \\
\text { Rainfall } \\
\text { Volume }\end{array}$} & Period & $\begin{array}{l}\text { Bud Sprouting } \\
\left(15^{\text {th }} \text { August }\right. \\
\text { to } \quad 2^{\text {nd }} \\
\text { September }\end{array}$ & $\begin{array}{l}\text { Shoot Elongation } \\
\text { and } \quad \text { Flower } \\
\text { initiation } \\
\text { (3rd September to } \\
\text { 2o }^{\text {th }} \text { October) }\end{array}$ & $\begin{array}{l}\text { Initial Vegetative } \\
\text { Phase } \\
\left(11^{\text {th }} \text { November to }\right. \\
\left.4^{\text {th }} \text { December }\right)\end{array}$ & \\
\hline & & Index & \multicolumn{3}{|c|}{ Aggregate of rainfall over respective phases } & \\
\hline & & Strike I $(<)$ & $69 \mathrm{~mm}$ & $114 \mathrm{~mm}$ & $46 \mathrm{~mm}$ & \\
\hline & & Strike II $(<)$ & $30 \mathrm{~mm}$ & $70 \mathrm{~mm}$ & $20 \mathrm{~mm}$ & \\
\hline & & Exit & $0 \mathrm{~mm}$ & $0 \mathrm{~mm}$ & $0 \mathrm{~mm}$ & \\
\hline & & $\begin{array}{l}\text { Rate I } \\
(\mathrm{Rs} / \mathrm{mm})\end{array}$ & 351 & 390 & 200 & \\
\hline & & $\begin{array}{l}\text { Rate II } \\
(\mathrm{Rs} / \mathrm{mm})\end{array}$ & 2878 & 1612 & 740 & \\
\hline & & $\begin{array}{l}\text { Maximum } \\
\text { Payout (Rs) }\end{array}$ & 1,00000 & $1,30,000$ & 20,000 & \\
\hline & & $\begin{array}{l}\text { Total Payout } \\
\text { (Rs) }\end{array}$ & $2,50,000$ & & & \\
\hline \multirow[t]{10}{*}{2} & \multirow{9}{*}{$\begin{array}{l}\text { Excess } \\
\text { Rainfall } \\
\text { Volume }\end{array}$} & \multirow[t]{2}{*}{ Period } & Phase I & Phase II & Phase III & Phase IV. \\
\hline & & & $\begin{array}{c}\text { Flower } \\
\text { initiation and } \\
\text { Blooming } \\
\left(1^{\text {th }} \text { October to }\right. \\
10^{\text {th }} \\
\text { November })\end{array}$ & $\begin{array}{c}\text { Vegetative Phase } \\
\left(\mathbf{I}^{\text {st }} \text { March to } 31^{\text {st }}\right. \\
\text { March })\end{array}$ & $\begin{array}{c}\text { Senescence } \\
\text { I }^{\text {st }} \text { April to } 30^{\text {th }} \\
\text { May }\end{array}$ & $\begin{array}{c}\text { Dormancy } \\
\text { I }^{\text {st }} \text { May to } 31^{\text {st }} \\
\text { May }\end{array}$ \\
\hline & & Index & \multicolumn{3}{|c|}{$\begin{array}{c}\text { Maximum of } 3 \text { consecutive days cumulative rainfall in } \\
\text { respective phases }\end{array}$} & \\
\hline & & Strike $\mathrm{I}(>)$ & $25 \mathrm{~mm}$ & $50 \mathrm{~mm}$ & $50 \mathrm{~mm}$ & $50 \mathrm{~mm}$ \\
\hline & & Strike II(>) & $50 \mathrm{~mm}$ & $125 \mathrm{~mm}$ & $125 \mathrm{~mm}$ & $125 \mathrm{~mm}$ \\
\hline & & Exit & $100 \mathrm{~mm}$ & $150 \mathrm{~mm}$ & $150 \mathrm{~mm}$ & $150 \mathrm{~mm}$ \\
\hline & & $\begin{array}{l}\text { Rate } \\
(\mathrm{Rs} / \mathrm{mm})\end{array}$ & 425 & 240 & 240 & 240 \\
\hline & & $\begin{array}{l}\text { Rate } \\
(\mathrm{Rs} / \mathrm{mm})\end{array}$ & 1488 & 480 & 480 & 480 \\
\hline & & $\begin{array}{l}\text { Maximum } \\
\text { Payout(Rs) }\end{array}$ & 85000 & 30000 & 30000 & 30000 \\
\hline & & $\begin{array}{l}\text { Total Payout } \\
\text { (Rs) }\end{array}$ & 175000 & & & \\
\hline \multirow[t]{2}{*}{3} & \multirow{2}{*}{$\begin{array}{l}\text { Decrease in } \\
\text { Day } \\
\text { Temperature }\end{array}$} & \multirow[t]{2}{*}{ Period } & Phase I & Phase II & Phase III & \\
\hline & & & $\begin{array}{l}\text { Bud Sprouting } \\
\left(26^{\text {th }} \text { August to }\right.\end{array}$ & $\begin{array}{l}\text { Shoot Elongation } \\
\left(10^{\text {th }} \text { September to }\right.\end{array}$ & $\begin{array}{l}\text { Flower initiation } \\
\left(\mathrm{I}^{\text {st }} \text { October to } 10^{\text {th }}\right.\end{array}$ & \\
\hline
\end{tabular}




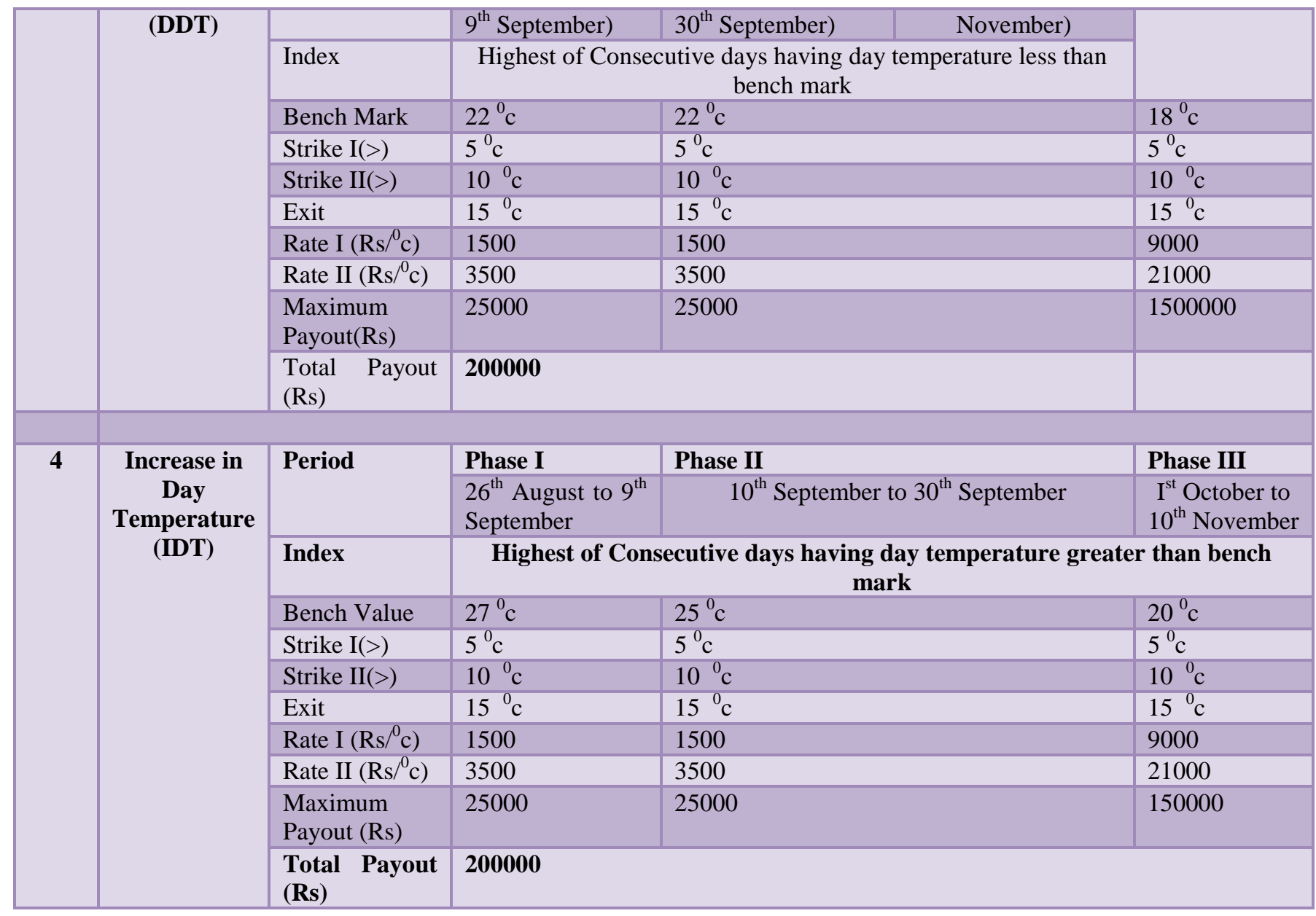

Table.3 Dimensions of experimental plot

\begin{tabular}{|c|c|c|c|c|}
\hline \multirow{2}{*}{ Crop } & \multicolumn{2}{|c|}{ Plot Size } & \multirow{2}{*}{$\begin{array}{c}\text { Diagonal } \\
\text { distance }\end{array}$} & $\begin{array}{c}\text { Area of the plot in } \\
\text { terms of Hectare }\end{array}$ \\
\cline { 2 - 4 } & Length & Breadth & 7.07 meter & $1 / 400$ th of a hectare \\
\hline Saffron & 5 meter & 5 meter & .
\end{tabular}

Table.4 Time schedule of CCEs activities

\begin{tabular}{|l|l|l|l|l|}
\hline $\begin{array}{l}\text { Name of the } \\
\text { Crop }\end{array}$ & $\begin{array}{l}\text { Randomly } \\
\text { Selection of } \\
\text { Village }\end{array}$ & $\begin{array}{l}\text { Date of } \\
\text { Submission of } \\
\text { Exhaustive list }\end{array}$ & $\begin{array}{l}\text { Randomly } \\
\text { selection of } \\
\text { Farmers }\end{array}$ & $\begin{array}{l}\text { Cut off date for } \\
\text { receiving CCE } \\
\text { results }\end{array}$ \\
\hline Saffron & $15^{\text {th }} \mathrm{July}$ & $25^{\text {th }} \mathrm{July}$ & $30^{\text {th }} \mathrm{July}$ & $20^{\text {th }}$ November \\
\hline
\end{tabular}

Table.5 CCEs format for submission of yield data

\begin{tabular}{|l|l|l|l|l|l|l|l|}
\hline $\begin{array}{l}\text { Nam of the } \\
\text { district }\end{array}$ & $\begin{array}{l}\text { Name of the } \\
\text { Agri Sub- } \\
\text { Division }\end{array}$ & $\begin{array}{l}\text { Name of } \\
\text { the Block }\end{array}$ & $\begin{array}{l}\text { Name of } \\
\text { the Circle }\end{array}$ & $\begin{array}{l}\text { Name of } \\
\text { the } \\
\text { Village }\end{array}$ & $\begin{array}{l}\text { Name of } \\
\text { the saffron } \\
\text { Grower }\end{array}$ & $\begin{array}{l}\text { Date of } \\
\text { CCE }\end{array}$ & $\begin{array}{l}\text { Dry weight of } \\
\text { saffron/25m } \\
\text { Experimental } \\
\text { Plot }\end{array}$ \\
\hline
\end{tabular}


Table.6 Format for reporting Crop Cutting Experiment Results

\begin{tabular}{|c|c|c|}
\hline Sl No. & Particulars & \\
\hline 1 & Name of the District & \\
\hline 2 & Name of the Agri. Sub-Division & \\
\hline 3 & Name of the Block & \\
\hline 4 & Name of Agri. Sector & \\
\hline 5 & Name of the Circle & \\
\hline 6 & Name of the Gram Panchayet & \\
\hline 7 & Name of the Cultivator where actual CCE conducted & \\
\hline 8 & Operational size of the holding of Farmer & \\
\hline 9 & Name of the crop & \\
\hline 10 & System of Cultivation & Scientific/Traditional \\
\hline 11 & Corm used/Kanal & \\
\hline 12 & Whether Manure/ FYM used in the plot & Yes/ No \\
\hline 13 & If yes, quantity of manure/FYM used (in per Kani) & \\
\hline 14 & Whether Chemical Fertilizer used in the plot & Yes/ No \\
\hline 15 & If yes, quantity of Chemical fertilizer used( in per Kanal ) & \\
\hline 16 & Time of sowing & (Early / Normal/ Late). \\
\hline 17 & Date of last flower picking & \\
\hline 18 & $\begin{array}{l}\text { Total area under crop (kanal) in respect of cultivator for which } \\
\text { CCE's is under taken }\end{array}$ & \\
\hline 19 & Age of the filed where CCE's is under taken & $\mathrm{I}^{\text {st }}$ year $/ 2^{\text {nd }}$ Year $/ 3^{\text {rd }}$ Year $/ 4^{\text {th }}$ Year/Above 4 years \\
\hline 20 & Length of the field (in footsteps ) & \\
\hline 21 & Breadth of the field (in footsteps ) & \\
\hline 22 & Pair of random number selected & \\
\hline 23 & Fresh Weight of the Produce obtained in CCE's in grams & \\
\hline 24 & Moisture Percentage in the produce obtained in CCE's & \\
\hline 25 & $\begin{array}{l}\text { Date of taking total Dry Weight of the Produce obtained in } \\
\text { CCE's }\end{array}$ & \\
\hline 26 & Dry Weight of the Produce obtained in CCE's ( in gm) & \\
\hline 27 & $\begin{array}{l}\text { Normal Average yield in ( Kgs / Kanl) where CCE's } \\
\text { undertaken ( as per farmer experience) }\end{array}$ & \\
\hline 28 & $\begin{array}{l}\text { Production obtained through CCE's in respect of Normal } \\
\text { average yield is }\end{array}$ & Normal/Good/Bad \\
\hline 29 & Remarks about Production observed & \\
\hline 30 & Whether the selected field was irrigated or un-irrigated & \\
\hline 31 & If irrigated the source of irrigation & \\
\hline 32 & Land type where CCE is undertaken & Upland/ Medium Land/ Low Land \\
\hline 33 & Weather condition during Crop season & Normal / Drought/flood \\
\hline 34 & Extent of damage by pests or any disease & \\
\hline
\end{tabular}


Figure.1 Saffron production and productivity trend over years (2009 to 2017)

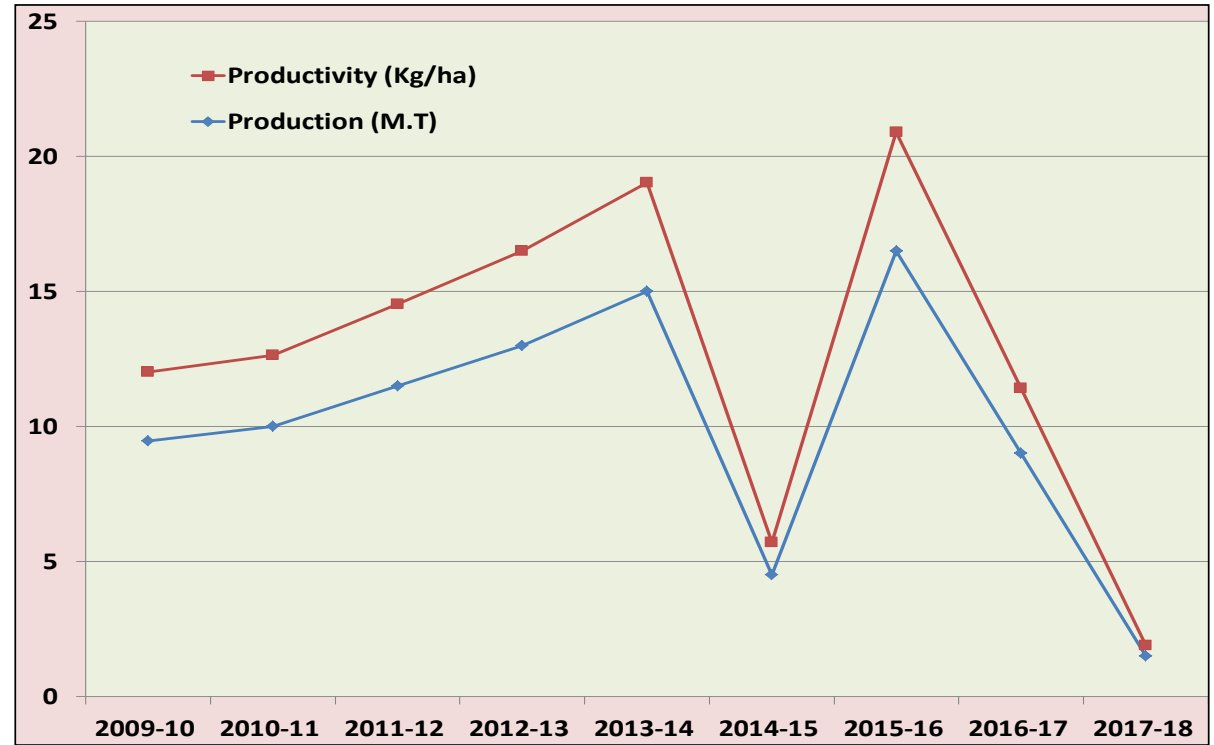

Figure.2 Erratic precipitation pattern during critical stages of saffron crop over growth years (2014-2017)

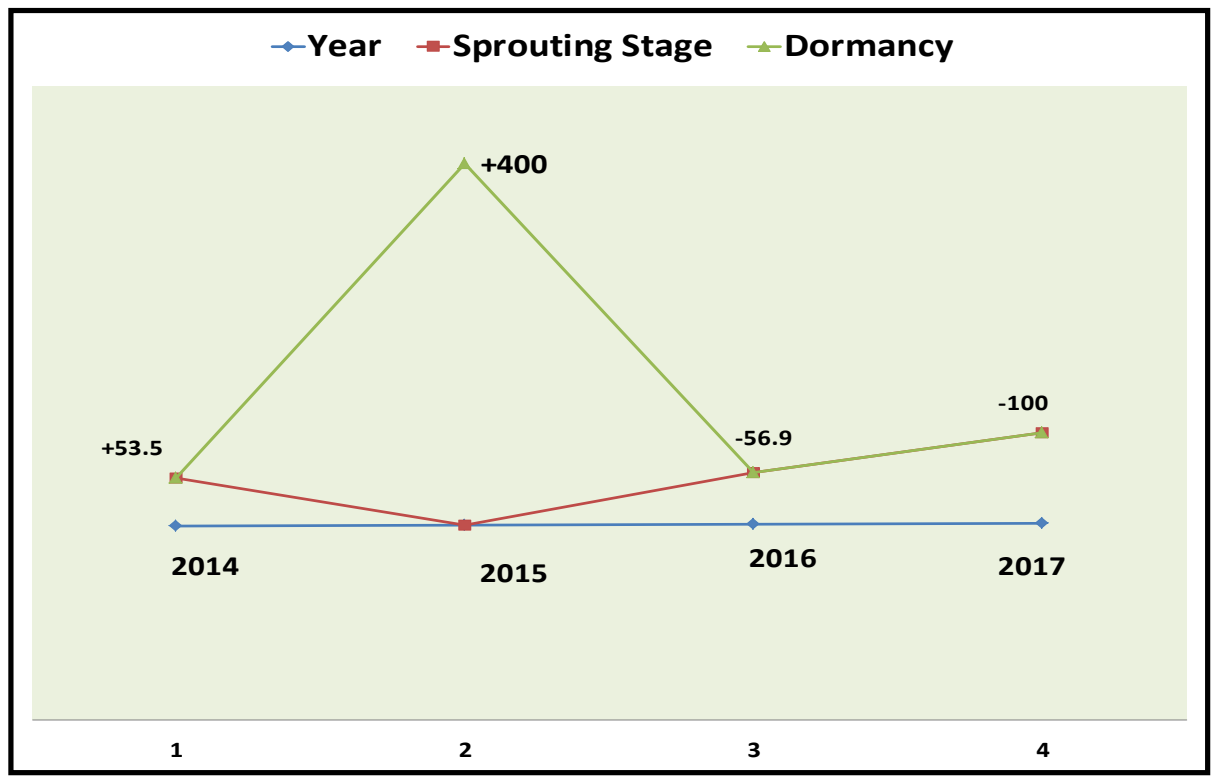


Figure.3 Weather parameters recorded during flowering period-averaged over years

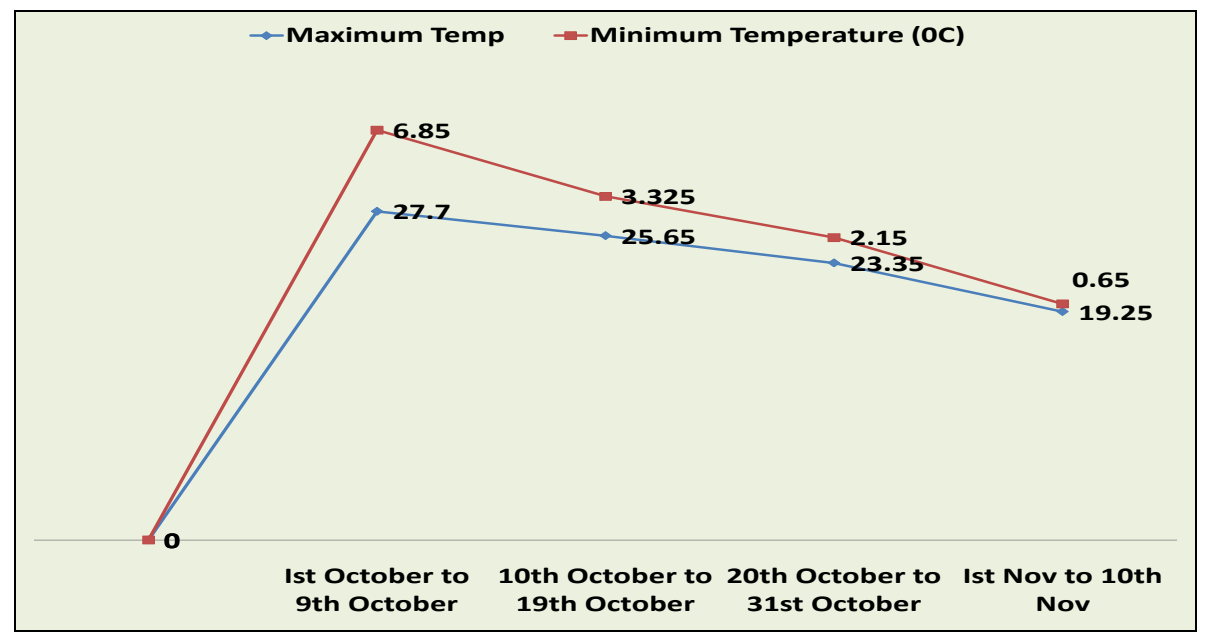

Figure.4 Stratified Random Sampling

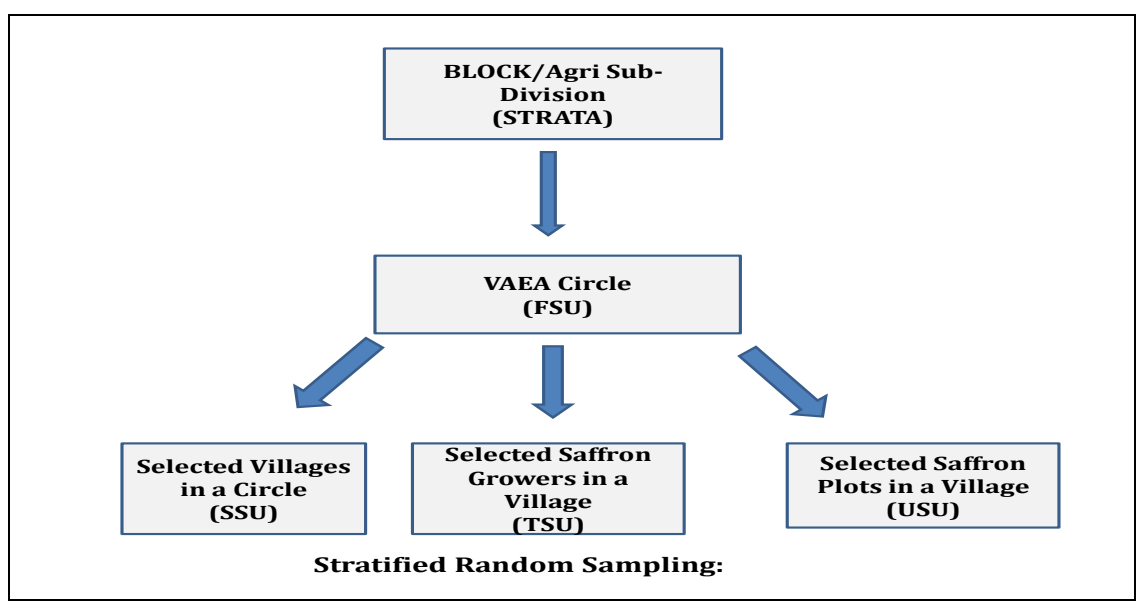

Figure.5 Site selection plan under CCEs in saffron

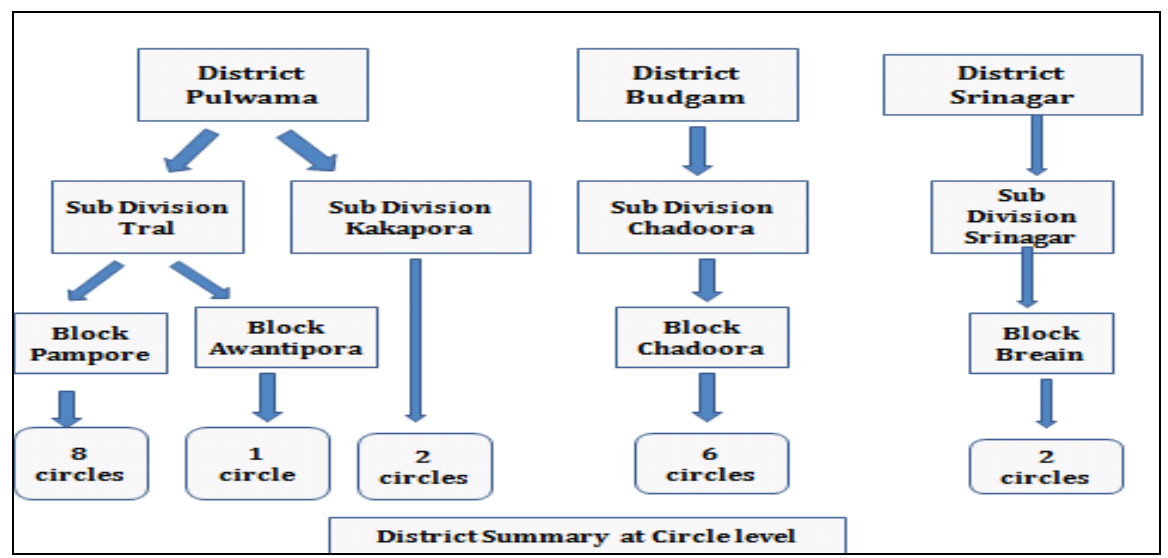


Figure.6 Procedure: for locating an experimental plot for crop cutting experiments (Square plot of Size $5 \times 5 m$ )

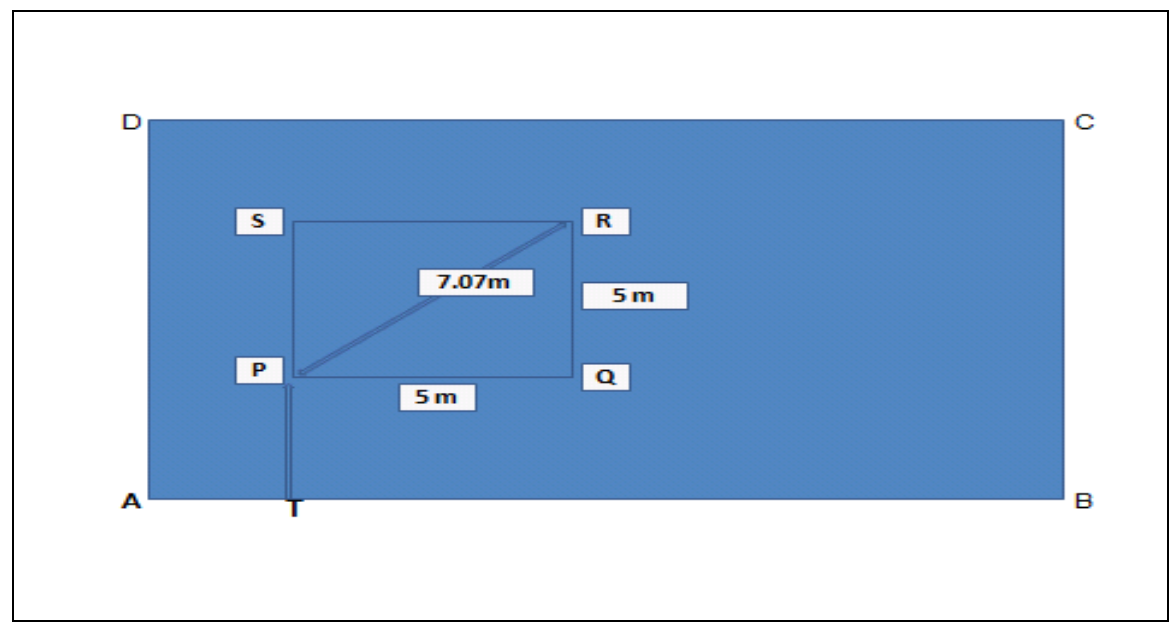

\section{Deficit rainfall}

Weather data averaged over two years recorded very high day temperature during October ranging from $23.3^{\circ} \mathrm{C}$ to $27.7^{\circ} \mathrm{C}$ and was accompanied with low night temperatures ranging from $3.3^{\circ} \mathrm{C}$ to $6.8^{\circ} \mathrm{C}$ (Figure 3).

High day temperatures by $3-7^{0} \mathrm{C}$ above normal was observed to be responsible for delaying the process of flowering followed by anthesis. However, $I^{\text {st }}$ fortnight of November recorded normal day temperature $\left(19.2^{\circ} \mathrm{C}\right)$ but was accompanied with very low night temperature $\left(0.65^{\circ} \mathrm{C}\right)$ (Figure 3$)$.

Deficit moisture availability once covered as trigger weather under crop insurance policy will cover the yield losses based on deviation to the maximum payout value of Rs 250,000. Water availability during sprouting stage ensures $40 \%$ yield gain over moisture stress cultivation due to activation of meristematic regions from apicular, axillary and lateral buds. Water deficit over a period of 87 days $\left(15^{\text {th }}\right.$ August to $11^{\text {th }}$ November) is categorized under two different strike rate, viz; strike 1 as $<229 \mathrm{~mm}$ and strike 2 as $<120 \mathrm{~mm}$. Out of total payout of Rs 250000 during pre and post sprouting stages maximum pay out of Rs 1, 30,000 is earmarked under phase- II(Shoot elongation and flower formation) followed by Rs 1,00000 in Phase I (Bud sprouting) and Rs 20,000 for phase III (Initial vegetative). Table 2. Insurance cover during this period will ensure financial safety against yield losses on account of rainfall deficit.

\section{Excess rainfall}

Similarly excess precipitation during Flower initiation and Blooming (15 $5^{\text {th }}$ October to $10^{\text {th }}$ November), Vegetative Phase ( $\mathrm{I}^{\text {st }}$ March to $31^{\text {st }}$ March), Senescence (I ${ }^{\text {st }}$ April to $30^{\text {th }}$ May) and Dormancy ( $\mathrm{I}^{\text {st }}$ May to $31^{\text {st }}$ May) leads to crop failure and is thus considered trigger weather. A total Payout of Rs 1, 75,000 is considered for a trigger weather covering excess rainfall to the extent of $>175 \mathrm{~mm}$ as strike I and $>425 \mathrm{~mm}$ as strike II .Maximum payout of Rs 85,000 with a payout rate of Rs $425 / \mathrm{mm}$ as Rate I and Rs $1488 / \mathrm{mm}$ as Rate II is considered during phase-1 (Flower initiation and Blooming) as excess rain during this period would lead to saffron flower loss. Whereas for other phases a uniform maximum payout of Rs 30000 is considered with Rs $240 / \mathrm{mm}$ as Rate I and Rs 480/mm as Rate-II for strike I and II excess rainfall (Table 2). 
Decrease and Increase in Day Temperature (DDT)

On the basis of trigger weather for temperatures, uniform term sheets were framed based on "Adverse Weather Incidence" leading to crop loss, on account of Decrease and Increase in Day Temperature by $>5^{\circ} \mathrm{c}$ as strike $\mathrm{I}$ and $>10{ }^{\circ} \mathrm{c}$ as strike II from a bench value for decrease in temperature of $22^{\circ} \mathrm{c}$ during sprouting stage and $18^{\circ} \mathrm{c}$ during flower initiation stage and bench value for increase in temperature of $27{ }^{\circ} \mathrm{c}$ during Bud Sprouting (26 $6^{\text {th }}$ August to $9^{\text {th }}$ September $), 25$ ${ }^{0} \mathrm{c}$ during Shoot Elongation $\left(10^{\text {th }}\right.$ September to $30^{\text {th }}$ September ) and $20{ }^{\circ} \mathrm{c}$ during Flower initiation ( $\mathrm{I}^{\text {st }}$ October to $10^{\text {th }}$ November ).For yield losses on account of decrease and increase in day temperature maximum pay out of Rs 1,50,0000 is considered for flower initiation $\left(\mathrm{I}^{\text {st }}\right.$ October to $10^{\text {th }}$ November) associated with a pay out of Rs $9000 /{ }^{\circ} \mathrm{c}$ as Rate I and Rs $21000 /{ }^{\circ} \mathrm{c}$ as Rate II. Payout during sprouting phases is uniformly considered at Rs 25000 /phase associated with a payout rate of Rs $1500 /{ }^{\circ} \mathrm{c}$ as Rate I and Rs $3500 /{ }^{\circ} \mathrm{c}$ as Rate II. Yield losses associate with decrease and increase in day temperatures during the trigger points is valued with a total payout of Rs 2, 00000 for each trigger weather (Table 2).

\section{Payout}

Payout arises only in case of Adverse Weather Incidence (AWI), Which is equivalent to the deviation between "Trigger Weather" and "Actual Weather" Data recorded at a "Reference Weather Station" during the specified time period. In case of AWI all the insured cultivators growing the Notified Crop in the Reference Unit Area are deemed to have suffered the same level of AWI and the same proportion of crop-loss, and become eligible for the same rate of Payouts.

\section{Pradhan Mantri Fasal Bima Yojna (PMFBY)}

\section{Basic principles}

\section{Sampling design}

The sampling design adopted in the crop cutting surveys of saffron is Multi-stage

\section{Stratified Random Sampling}

The traditional Agri. Sub-divisions cultivating the target crop have to be taken as strata, the selected V.A.E.A. circles, within the Block as first stage units (fsu), selected village in a circle as a second stage unit (ssu), selected cultivators in a village as a third stage units and the selected plots are the ultimate stage of sampling (Figure 4).

\section{Size of experimental plot}

The size and shape of the experimental plot for saffron crop is square of dimension $(5 \mathrm{~m} \mathrm{x}$ 5m) (Table 3).

Time schedule for carrying out different activities for undertaking CCE and submission of CCE result

October and November months are considered critical periods of CCEs (Table 4).

Steps in different activities in crop cut evaluation

\section{Selection of crop cut experimental sites at} circle level

Evaluation study need to be carried over 19 saffron growing circles $(11$ circles in district Pulwama, 6 circles in district Budgam and 2 circles in District Srinagar) with random selection of 2 villages/Circle and 5 experimental sites in each circle village. Thus, 
total number crop cut for saffron would be one hundred ninety $(19 \times 2 \times 5=190)$ from 4 subdivisions of saffron growing districts (Pulwama, Budgam, Srinagar) (Figure 5).

\section{Procedure for village selection for taking CCEs of saffron}

38 villages from 19 circles need to be selected randomly at circle level. From the exhaustive list of villages in a Circle, a sample of 2 villages would be selected with equal probability. It will be mandatory that the villages to be selected should have some area under the programme crop (Rejuvenated under National Saffron Mission). If however, some of the villages in the sample do not have any area under any of the programme crops, this will be replaced by other villages. For this purpose a list of suitable number of additional villages selected at random will have to be kept ready for use.

\section{Procedure for Selection of saffron growers plot (experimental site) for taking crop cut}

For conducting the CCEs, a complete list of the saffron growers for growing programme crops in each of the selected villages will be prepared. From this list required number of saffron grower's plot (5 in each village) would be selected randomly using random number table (Remainder approach).

\section{Experimental materials required}

Each member of the staff taking the crop cut is to be supplied with uniform equipment for his experimental work, which is known as Crop Cutting Experiment Kit. This Crop cutting Experiment Kit has to be keept ready in Circle/ Sector Office in a sufficient numbers. The CCE Kit consists of; i). One measuring tape, $30 \mathrm{~m}$ length .ii) Sufficient long string / rope, minimum $30 \mathrm{~m}$ length, iii) Weighing electronic balance, IV) Electric/Vacuum dryers, v) Moisture analyzer, vi) Pegs/Straight bamboo poles (4 nos.), vii) Random number table, viii) Willow Baskets and ix) Note Book.
Locating an Experimental Plot for Crop Cutting Experiments (Square plot of Size 5x5m)

\section{Procedure}

In each selected field one Square size (5 m x 5 $\mathrm{m})$ plot is to be located at random. This is not to be done earlier than the date fixed for harvesting. Before a plot is located, make sure that the field is already selected (Figure 6). The procedure for locating a random plot is as indicated below for a Square plot of size $(5 \mathrm{~m}$ x $5 \mathrm{~m}$ )

Let the four corners of the field in which crop cutting experiment plot is to be located be named as ABCD.

Let the point " $A$ " represents the south-west corner of the field. For locating south-west corner of the field, the Official taking the crop-cut should stand at this point facing the field and keeping the cut area to his right.

The point A, the South -West corner of the field ABCD will be the starting point. For convenience, fix a bamboo pole at the starting point.

From the starting point measure the length and breadth of the field by footsteps.

Deduct 7 footsteps from both length and breadth

Suppose the length and breadth of the fields as shown in Figure below is 40 footsteps and 28 footsteps respectively. Then the length and breadth after deducting 7 footsteps, then length and breadth will be 33 and 21 .

Now select a pair of random numbers one for length and the other for the breadth from the random number table. In the above example, the random number for both length and 
breadth should be of two digits. Suppose Pair of random numbers for the fields for length is 14 and for breadth is 12 .

To get the experimental plot, now start walk 14 steps from the starting point " $\mathrm{A}$ " along the length of the field. Call this point as " $T$ ". Having arrived at this point " $T$ ", enter into the field along a direction at right angle to the length of the field to a distance of 12 footsteps corresponding to the random number selected for the breadth. Call this point as "P".

This point "P" will be the south-west corner of the desired plot "PQRS" to be harvested. Place peg at "P"

From "P" proceed in a direction parallel to AB. With the help of tape measure a distance PQ which is exactly up to 5 meters.

Place another peg at Q. Keep the zero point of the tape at "Q", open a total length of 12.07 meters of the tape and keep the point of the tape showing the length 12.07 meters at "P".

Now keeping the two point's viz. 0 and 12.07 meters on $Q$ and $P$ respectively, stretch the tape and fix the point " $R$ " such that "PR" is of length 7.07 meters and $\mathrm{QR}$ is equal to 5 meters. It will be seen that the angle PQR is a right angle.

Place peg at point " $\mathrm{R}$ " which is the third corner of the plot to be located.

For obtaining the fourth point keep the two points in the tape marked 0 and 12.07 meters respectively at $\mathrm{P}$ and $\mathrm{Q}$ respectively and similar process to be adopted as stated in above paragraph to get the fourth point "S".

Place the fourth peg at "S". The pegs PQRS indicate the four corners of the plot to be harvested.
It should be noted that the plot PQRS should be laid out in such a way that the point $\mathrm{P}$ is the south -west corner of the plot to be harvested and will be the point nearest to the South West corner of the whole field.

\section{Flower picking and other operations}

Ensure flower picking of all the 2 days old opened saffron flowers falling inside the cut area demarcated by the string on the first picking day and take the fresh weight of the produce. The weight of the produce should be recorded in notebook in Prescribed CCE Format.

Ensure pistil separation within 5 hours of flower picking take the fresh weight of the produce. The weight of the produce should be recorded in notebook in Prescribed CCE Format.

Dry saffron pistils in electric/Vacuum dryers at $60^{\circ} \mathrm{c}$ up to a safe moisture level of $10-12 \%$ as per ISO 3632 quality standards.

Repeat same procedure for each subsequent flower picking from the demarcated area and take the total dry weight of saffron and the moisture percentage.

Crop cutting experiment shall be conducted in presence of the officers as desired by the authority

Dry weight and CCEs experimental results to be communicated with in 3 weeks from the date of last picking (Table 5 and 6).

Saffron Insurance policy will ensure financial stability to saffron growers in the $\mathrm{J}$ and $\mathrm{K}$ state who are despondent about future of saffron due to weather instability. Saffron insurance once implemented shall save saffron growers from annual exchequer loss of about Rs 200 crores as observed in the year 2017. 


\section{Acknowledgement}

Authors acknowledge the financial support rendered by Ministry of Agriculture Govt of India under National Saffron Mission

\section{References}

NCIP, 2014. National Group Insurance Programme (NCIP). Ministry of Agriculture. Department of Agriculture \& Cooperation

Nehvi, F.A and Salwee Yasmin. 2017. Advances in saffron research for integrated development of saffron in Kashmir, India. 2017. Acta Hortic 1184. ISHS 2017:63-68.

Nehvi, F.A., Dhar, J.K., Sheikh, S.S., Iqbal, A.M. and John, A.A. 2018. Conventional postharvest practices and their impact on saffron quality - a study. Acta Horticulturae 1200:139-144.

Nehvi, F.A., Salwee Yasmin., Sabina Naseer, Shahina A. Nagoo, Bashir Ahmad Elahi., Aijaz Ahmad Lone and Aflaq
Hamid 2017. Irrigation -Acritical input for enhancing production and productivity of saffron in Jammu and Kashmir. Manual Series 04 under Economic Revival of J\&K saffron sector.SKUAST-K

PMFBY. 2016. Operational guidelines. Department of Agriculture, Cooperation and Farmers Welfare Ministry of Agriculture \& Farmers Welfare Krishi Bhawan, New Delhi-110001

Salwee Yasmin and Nehvi, F.A. 2018. Phenological Growth Stages of Saffron (Crocus sativus L.) under Temperate Conditions of Jammu and KashmirIndia. Int.J.Curr.Microbiol.App.Sci. 7(04): 3797-3814.

SalweeYasmin, F.A. Nehvi and Nisar Ahmad Qazi. 2016. Economic loss of Saffron (Crocus sativus L.) caused by Rhizoctonia solani under temperate conditions of Kashmir-an emerging threat. Journal of Cell and Tissue Research. 16(1): 5531-5535 (2016)

\section{How to cite this article:}

Nehvi F. A. and Salwee Yasmin. 2019. Saffron (Crocus sativus L.) Crop Insurance to Mitigate ill Effects of Climate change - a Priority of Jammu and Kashmir State. Int.J.Curr.Microbiol.App.Sci. 8(01): 2972-2984. doi: https://doi.org/10.20546/ijcmas.2019.802.347 